\title{
Review
}

\section{The role of p53 in neuronal cell death}

\author{
RS Morrison ${ }^{\star, 1}$ and Y Kinoshita ${ }^{1}$ \\ ${ }^{1}$ Department of Neurological Surgery, University of Washington School of \\ Medicine, Box 356470, Seattle, Washington 98195-6470, USA \\ * Corresponding author: R Morrison, Department of Neurological Surgery, \\ University of Washington School of Medicine, Box 356470, Seattle, \\ Washington 98195-6470, USA Tel: (206) 543-9654; Fax: (206) 543-8315; \\ E-mail: yael@u.washington.edu
}

Received 10.5.00; revised 10.7.00; accepted 10.7.00

Edited by G Melino

\begin{abstract}
The p53 tumor suppressor gene is a sequence-specific transcription factor that activates the expression of genes engaged in promoting growth arrest or cell death in response to genotoxic stress. A possible role for p53-related modulation of neuronal viability has been suggested by the finding that p53 expression is elevated in damaged neurons in acute models of injury such as ischemia and epilepsy and in brain tissue samples derived from patients with chronic neurodegenerative diseases. Moreover, the absence of p53 has been shown to protect neurons from a wide variety of acute toxic insults. Signal transduction pathways associated with p53induced cell death are being unraveled and suggest that intervention may prove fruitful in maintaining neuronal viability and restoring function following cytopathic insults. Cell Death and Differentiation (2000) 7, 868-879.
\end{abstract}

Keywords: caspase; Bax; excitotoxicity; neuronal cell death; apoptosis

\begin{abstract}
Abbreviations: $A \beta$, beta-amyloid protein; $A L S$, amyotrophic lateral sclerosis; APP, amyloid precursor protein; ATM, ataxia telangiectasia gene; CNS, central nervous system; ERK, extracellular signalregulated kinase; GAPDH, glyceraldehyde-3-phosphate dehydrogenase; IGF, insulin-like growth factor; JNK, c-jun N-terminal kinase; MAP kinase, mitogen-activated protein kinase; MEK, MAP kinase kinase; MPTP, 1-methyl-4-phenyl-1,2,3,6- tetrahydropyridine; NGF, nerve growth factor; NMDA, N-methyl-D-glutamate; PI3-K, phosphatidylinositol 3-kinase; PIG's, p35-inducible genes; $\mathrm{QA}$, quinolinic acid; $\mathrm{Rb}$, retinoblastoma gene; SOD-1, superoxide dismutase-1; TUNEL, terminal deoxynucleotidyl transferasemediated biotin dUTP nick end-labeling
\end{abstract}

\section{The p53 gene}

The p53 tumor suppressor gene encodes a nuclear phosphoprotein that functions as a key regulator of cell cycle progression and apoptosis. p53 is also recognized as belonging to a pathway responsible for DNA damage repair, which is critical for maintaining genomic stability. Loss or inactivation of the p53 tumor suppressor gene occurs in almost half of all human tumors ${ }^{1}$ and is considered a fundamental, predisposing event in the pathogenesis of many cancers. Patients carrying germ line mutations in p53 are at higher risk for developing a variety of tumors, ${ }^{2,3}$ and mice deficient in p53 display precocious tumor development. $^{4-7}$

The p53 protein is upregulated in response to a diverse array of cellular stresses, including DNA damage, hypoxia, oxidative stress, ribonucleotide depletion and oncogene activation. $^{8,9}$ p53 protein levels are largely regulated in response to injury by changes in protein degradation. Recent studies have demonstrated that p53 protein levels are regulated by the MDM2 protein through a ubiquitindependent, proteasome-mediated pathway. ${ }^{10,11}$ Stress signals result in stabilization of p53 protein through inhibition of MDM2-mediated degradation. The interaction between p53 and MDM2 is governed by phosphorylation reactions $^{12,13}$ and through protein-protein interactions such as those involving the p14ARF protein. ${ }^{14,15}$ The E2F1 transcription factor, which is involved in cell cycle progression and under certain circumstances mediates apoptosis, can also regulate p53 stabilization, in part, through transcriptional activation of ARF expression. ${ }^{16}$ Thus, a diverse but partially overlapping series of regulatory pathways may influence p53 protein levels. These regulatory pathways have been largely defined for non-neuronal cells, and there is little information regarding the regulation of p53 activity in neurons.

In response to cellular stress, p53 induces its biological response through the transcriptional transactivation of specific target genes. These downstream effectors have been characterized with respect to p53-mediated growth arrest, ${ }^{17}$ but the pathways associated with p53-mediated apoptosis remain obscure. ${ }^{18}$ In addition to its transcriptional transactivating activity, p53 may promote apoptosis by repressing the expression of select genes. ${ }^{19,20}$ This particular action of p53 is not well understood, but it does not appear to depend on the presence of p53 consensus binding sites in the promoter region of repressed genes. Moreover, p53-mediated apoptosis may also occur through transcription-independent pathways requiring direct protein - protein interactions. ${ }^{21,22}$

\section{p53 expression changes in response to neuronal injury}

The demonstration that p53 promotes apoptosis has important implications for the central nervous system (CNS), where cell death is observed normally during development, in response to injury, and in neurodegenerative disorders such as Alzheimer's and Huntington's disease. ${ }^{23-26,}$ Neuronal injury, especially damage mediated by excitotoxicity, has 
Table 1 Various forms of brain injury or pathology associated with p53 induction

\begin{tabular}{|c|c|c|c|}
\hline Condition & p53 Detected as & Neurons affected & References \\
\hline \multicolumn{4}{|l|}{ In vivo } \\
\hline Adrenalectomy & mRNA/protein & DG & 154 \\
\hline Alzheimer's disease & protein & $C x^{b}$ & $44,45,155$ \\
\hline $\mathrm{A} \beta$ transgenic mouse & protein & $\mathrm{Cx}, \mathrm{Hp}$ & 46 \\
\hline Amyotrophic lateral sclerosis & protein & SMN & 45 \\
\hline Angelman Syndrome & protein & $\mathrm{Cb}, \mathrm{Hp}^{\mathrm{c}}$ & 50 \\
\hline Down's Syndrome & protein & $\mathrm{Cx}, \mathrm{Cb}$ & 45,52 \\
\hline Hereditary DNA repair disorders & protein & $\mathrm{Cb}$ & 156 \\
\hline Ionizing radiation & protein & $\mathrm{Ob}, \mathrm{Cx}, \mathrm{Cb}, \mathrm{Hp}$ & 34 \\
\hline Ischemia & mRNA/protein & $\mathrm{Cx}, \mathrm{St}, \mathrm{Rt}$ & $42,43,157-159$ \\
\hline Methamphetamine & protein & St & 62 \\
\hline Photochemical injury & protein & Cx & 160 \\
\hline $\mathrm{Rb}$ deficiency & protein & $\mathrm{NS}^{\mathrm{a}}$ & 65 \\
\hline Seizures/excitotoxicity & mRNA/protein & HP, Th, Am, Cx, PCx, St & $35-39,161$ \\
\hline Traumatic brain injury & mRNA & Cx, Hp, Th & $40,41,162$ \\
\hline \multicolumn{4}{|l|}{ In vitro } \\
\hline Cytosine arabinoside & protein & $\mathrm{Sp}, \mathrm{Cb}$ & 55,70 \\
\hline Dopamine & p53 phosph. & $\mathrm{Cb}$ & 163 \\
\hline Glutamate & mRNA/protein & $\mathrm{Cb}$ & 53,54 \\
\hline 6-Hydroxydopamine & protein & PC12 cells & 164 \\
\hline Hypoxia & protein & Cx & 57 \\
\hline Ionizing radiation & protein & $\mathrm{Hp}$ & 56 \\
\hline NGF withdrawal & protein & Sp, PC12 cells ${ }^{d}$ & 74,165 \\
\hline
\end{tabular}

${ }^{a}$ Not specifically stated. Ref. ${ }^{65}$ indicated that immunocytochemical expression of p53 was increased in the central nervous system of Rb-mutant mice. Also, the absence of p53 inhibited cell death (TUNEL positive cells) in the central nervous system of Rb-mutant mice. ${ }^{b}$ These authors reported that immunohistochemical staining demonstrated increased p53 expression and DNA fragmentation in overlapping populations of cortical neurons, and cortical and white matter glial cells distributed in regions damaged by neurodegeneration ${ }^{44} \mathrm{~A}$ separate study demonstrated increased p53 in glial cells only. ${ }^{155} \mathrm{c} 53$ immunoreactivity was detected in neurons in both the mouse model of Angelman Syndrome and in postmortem samples from patients with Angelman Syndrome. ${ }^{\mathrm{d}} \mathrm{p} 53$ immunoreactivity shifted from the cytoplasm to the nucleus in response to NGF-induced neuronal differentiation in PC12 cells. ${ }^{165}$ These abbreviations indicate the brain region in which p53 was detected or the region from which cultured neurons were established. Am, Amygdala; Cb, cerebellum; Cx, cerebral cortex; DG, dentate granule neurons; Hp, hippocampus; Ob, olfactory bulb; PCx, parietal cortex; Rt, Retina; Sp, sympathetic neurons; Ss, sensory; SMN, spinal motor neurons, St, striatum; Th, thalamus

been associated with increased production of reactive oxygen species, ${ }^{27-30}$ and accumulation of single-strand DNA breaks. ${ }^{31}$ DNA strand breaks are capable of inducing p53 accumulation, ${ }^{32,33}$ which has prompted investigators to begin examining $\mathrm{p} 53$ for a role in regulating neuronal cell death.

Alterations in p53 mRNA and protein expression have been associated with neuronal damage in a variety of in vivo and in vitro model systems (Table 1). The in vivo models include acute injury and neurodegenerative disease. The range of acute injuries that results in p53 activation is diverse. These include adrenalectomy, which selectively promotes cell death in dentate granule cells in the hippocampus, ionizing radiation, methamphetamine administration, photochemical injury to the cerebral cortex, seizure induction produced by administration of excitatory amino acids, ischemic injury resulting from ligation of the middle cerebral artery and traumatic brain injury produced by direct impact to the cerebral cortex. In nearly all of these studies increased levels of p53 immunostaining were demonstrated in neurons. In several cases increased expression of the p53 protein was confirmed by protein immunoblotting. ${ }^{34,35}$

Among the acute injury models, damage resulting from neuronal stimulation by excitatory amino acids or corresponding receptor agonists has been strongly associated with p53 accumulation. The systemic injection of kainic acid, a potent excitotoxin which produces seizures associated with a defined pattern of neuronal cell loss, induced p53 expression in neurons exhibiting morphological evidence of damage $;^{36,37}$ pretreatment with a protein synthesis inhibitor prevented both kainic acid-induced p53 expression and neuronal damage. Activation of glutamate receptors by intrastriatal infusion of either N-methyl-D-aspartate (NMDA), the NMDA receptor agonist quinolinic acid (QA) or kainic acid produced a significant elevation in p53 levels in striatal neurons. ${ }^{35,38,39}$ These results suggest that p53 induction may be linked to apoptosis due to excitotoxicity associated with seizures and Huntington's disease.

Elevated expression of the p53 gene has also been observed following experimental traumatic brain injury. As early as $6 \mathrm{~h}$ post-injury, p53 mRNA is induced predominantly in neurons that are vulnerable to traumatic brain injury, such as those in the contused cortex, lateral and medial geniculate nuclei of the thalamus, and the CA3 and hilar neurons of the hippocampus. ${ }^{40}$ Interestingly, the administration of magnesium, which has been shown to be neuroprotective in experimental models of traumatic brain injury, significantly reduced p53 mRNA expression in a select population of injured neurons. ${ }^{41}$ Transient or permanent occlusion of the middle cerebral artery causes ischemia-induced cell death in striatal and cerebral cortical neurons, which is associated with a significant increase in the expression of p53 mRNA $^{42}$ and protein. ${ }^{43}$ In the cortex, p53 immunoreactivity was observed specifically in cortical neurons in areas surrounding the ischemic core (penumbra) one day after occlusion. Three days following middle 
cerebral artery occlusion, many neurons in the penumbra region were positively stained by terminal transferasemediated biotinylated-UTP nick end labeling (TUNEL staining). Since TUNEL labeling assesses DNA fragmentation associated with the late stages of cell death, and this occurred three days after occlusion, it is consistent with the concept that p53 may promote neuronal cell death in response to ischemia.

p53 immunoreactivity has also been detected in brain tissue derived from animal models of human neurodegenerative disease or from patients that have been diagnosed with a neurodegenerative disorder. Patients with Alzheimer's disease ${ }^{44,45}$ show increased p53 immunoreactivity in morphologically damaged neurons consistent with the detection of extensive p53 immunoreactivity in neurons from mice overexpressing the beta-amyloid peptide ( $\mathrm{A} \beta 1-$ 42) ${ }^{46}$ Abnormalities in the regulation of $A \beta$ expression and processing have been associated with the development of Alzheimer's disease and neuronal degeneration. ${ }^{4-49}$ In this particular mouse model, nuclear p53 immunoreactivity was detected in neurons that displayed cytoplasmic expression of the $\mathrm{A} \beta$ peptide and were TUNEL positive. A subset of neurons displayed both nuclear and cytoplasmic localization of the p53 protein whereas some neurons displayed only cytoplasmic localization. It is not clear from this report whether neurons exclusively expressing cytoplasmic p53 were also $\mathrm{A} \beta$ and TUNEL positive. The relationship between cytoplasmic p53 accumulation and neuronal cell death is currently unknown. However, this represents an interesting observation in light of recent findings that mutation of the E6-AP ubiquitin ligase in a mouse model of Angelman syndrome results in increased cytoplasmic abundance of the p53 protein in hippocampal pyramidal neurons and cerebellar Purkinje neurons. ${ }^{50}$ Animals expressing the Angelman mutation display motor dysfunction, inducible seizures and a deficiency in contextual learning. Increased p53 immunoreactivity was also observed in cerebellar Purkinje cells in the brain of a patient diagnosed with Angelman syndrome. Thus, increased levels of the p53 protein in Angelman syndrome resulting from abnormalities in the ubiquitination process may contribute to neuronal dysfunction. The brains of patients with Down's syndrome, a genetic disorder manifesting a similar pathology to Alzheimer's disease, have also been shown to express elevated levels of apoptosis effectors including the p53 protein. ${ }^{45,51,52}$ Increased p53 immunoreactivity has been localized in both neuronal and glial cell nuclei in Down's syndrome brain, ${ }^{45}$ suggesting that p53-mediated cell death pathways may not be restricted to neurons in certain neurodegenerative disorders. These results demonstrate that increased levels of the p53 protein are commonly associated with neuronal damage and cell death in mouse models of brain injury and neurodegeneration as well as in brain tissue samples derived from patients with neurological diseases.

The results obtained with in vitro models of neuronal injury are consistent with the data described above for the in vivo models. Excitotoxicity, which figured so prominently in the whole animal studies, is a potent inducer of p53 protein in cultured cerebellar granule neurons. ${ }^{53,54}$ Another potent stimulus for elevating p53 expression in cultured neurons is DNA damage induced by cytosine arabinoside $^{54,55}$ or ionizing radiation. ${ }^{56}$ Hypoxia in culture, which models the ischemia produced by middle cerebral artery occlusion, increases p53 protein expression in rat embryonic cortical neurons. ${ }^{57}$ The upregulation of $p 53$ is associated with neurons exhibiting morphological evidence of apoptosis and the extent of upregulation is dependent upon the duration of hypoxia. Stress induced changes in p53 expression are not limited to central nervous system neurons. For example, neuronal cell death induced by nerve growth factor withdrawal dramatically elevates p53 protein levels in cultured neonatal sympathetic neurons. ${ }^{58}$

These results collectively demonstrate that: (1) p53 mRNA or protein can be accumulated in multiple neuronal populations in both the peripheral and central nervous system; and (2) p53 is upregulated in response to a diverse array of cellular insults ranging from hypoxia, excitotoxicity to intracellular expression of the $\mathrm{A} \beta$ peptide. It is not presently known if these divergent cellular insults activate p53 by initiating damage to a common cellular component (i.e., oxidative damage to DNA). Nevertheless, these studies collectively suggest that p53 is widely involved in neuronal death in response to different forms of acute insults and neurological disorders.

\section{The relationship between p53 expression and neuronal cell death}

The relationship between p53 expression and neuronal cell death has been evaluated in numerous models of injury and disease (Table 2). p53-deficient mice or neurons derived from these mice have been used most often, but inhibitors of p53 expression or p53 function have also been used to evaluate the role of p53 in the context of neuronal injury. The absence of p53 has been shown to protect neurons in vivo from a wide variety of toxic insults including focal ischemia, ${ }^{59}$ ionizing radiation, ${ }^{34,60}$ MPTP-induced neurotoxicity, ${ }^{61}$ methamphetamine-induced neurotoxicity ${ }^{62}$ and adrenalectomy. ${ }^{63}$ A role for p53 has also been demonstrated for apoptosis associated with abnormal development. Homozygous deletion of the retinoblastoma gene $(\mathrm{Rb})$ results in extensive apoptosis in the peripheral and central nervous system, ${ }^{64}$ which is accompanied by increased levels of the $\mathrm{p} 53$ protein. ${ }^{65}$ Backcrossing Rb-mutant mice onto a p53 null background prevents cell death in the CNS of Rb-null embryos. p53 is also essential for developmental neuronal death in certain subpopulations of neurons. ${ }^{58}$ The naturally occurring developmental cell death of sympathetic neurons is dramatically reduced in $\mathrm{p} 53^{-/-}$and even $\mathrm{p} 53^{+/-}$animals.

Cultured neurons deficient in both p53 alleles exhibit protection from many toxic insults including DNA damaging agents, ${ }^{55,66-70}$ ionizing radiation, ${ }^{66,71}$ glutamate, ${ }^{53,54,72}$ hypoxia, ${ }^{57,73}$ and NGF withdrawal. ${ }^{58,74}$ In contrast to these results, cerebellar neurons lacking p53 die when transferred to a low potassium medium ${ }^{67}$ and postnatal cortical and hippocampal neurons also die after staurosporine exposure in a p53-independent manner. ${ }^{71}$

Clearly, the absence of p53 does not protect neurons against all forms of toxic insults. Cerebellar granule neuron 
Table 2 Effect of p53 deletion or inhibition on neuronal survival

\begin{tabular}{|c|c|c|c|}
\hline Condition & Protection & Neurons affected & References \\
\hline \multicolumn{4}{|l|}{ In vivo } \\
\hline Adrenalectomy & yes & $\mathrm{DG}$ & 63 \\
\hline Amyotrophic lateral sclerosis & no & SMN & 78 \\
\hline Developmental cell death & yes & Sp & 58 \\
\hline lonizing radiation & yes & $\mathrm{NS}^{\mathrm{b}}, \mathrm{Cb}$ & 34,60 \\
\hline Ischemia & yes & $\mathrm{Cx}$ & 59 \\
\hline Methamphetamine & yes & St & 62 \\
\hline Methylazoxymethanol & no & $\mathrm{Cb}$ & 60 \\
\hline MPTP & yes & St & 61 \\
\hline $\mathrm{Rb}$ deficiency & yes & $\mathrm{NS}^{\mathrm{a}}$ & 65 \\
\hline Seizures/excitotoxicity & yes/no & $\mathrm{Cx}, \mathrm{Hp}, \mathrm{St}, \mathrm{Th}$ & $35,38,79,80$ \\
\hline \multicolumn{4}{|l|}{ In vitro } \\
\hline Bleomycin & yes & $\mathrm{Cb}$ & 68 \\
\hline Camptothecin & yes & $\mathrm{Cx}, \mathrm{Hp}$ & 69 \\
\hline Cytosine arabinoside & yes & $\mathrm{Sp}, \mathrm{Cb}$ & $55,67,70$ \\
\hline Glutamate & yes & $\mathrm{Cx}, \mathrm{Hp}, \mathrm{Cb}$ & $53,54,72$ \\
\hline Hypoxia & yes & $\mathrm{Cx}$ & 57,73 \\
\hline lonizing radiation & yes & $\mathrm{Cx}, \mathrm{Hp}, \mathrm{Cb}$ & 66,71 \\
\hline Low potassium & no & $\mathrm{Cb}$ & 66 \\
\hline NGF withdrawal & yes/no & $\mathrm{Sp}, \mathrm{Ss}$ & $58,74,166,167$ \\
\hline Staurosporine & no & $\mathrm{Cx}$ & 71 \\
\hline
\end{tabular}

${ }^{a}$ Not specifically stated. Ref. ${ }^{65}$ indicated that immunocytochemical expression of p53 was increased in the central nervous system of Rb-mutant mice. Also, the absence of p53 inhibited cell death (TUNEL positive cells) in the central nervous system of Rb-mutant mice. ${ }^{b} \mathrm{Not}$ specifically stated. Ref. ${ }^{34}$ indicated that $\mathrm{p} 53^{-1-}$ mice were resistant to irradiation-induced cell death in the developing nervous system

death induced by methylazoxymethanol is not alleviated in p53-null mice. ${ }^{60}$ Another example relates to the role of p53mediated apoptosis in amyotrophic lateral sclerosis (ALS), a neurodegenerative disease characterized by degeneration and death of motor neurons in the anterior horn of the spinal cord, lower brainstem, and cerebral cortex. Transgenic mice that express the copper-zinc superoxide dismutase-1 (CuZn SOD1) mutations found in familial ALS kindred show progressive paralysis as a result of motor neuron cell loss. ${ }^{75-77}$ To assess the role of p53-mediated apoptosis in ALS, mice deficient in both $\mathrm{p} 53$ alleles $\left(\mathrm{p} 53^{-/-}\right)$were crossed with transgenic mice expressing the G93A mutation $\left(\mathrm{G} 3 \mathrm{~A}^{+}\right)$to create hybrid transgenic knockout mice $\left(\mathrm{G} 93 \mathrm{~A}^{+} /\right.$ p53 $\left.{ }^{-/-}\right)$. Unexpectedly, the absence of p53 in these transgenic mice had no statistically significant effect on disease onset, survival, or the extent of motor neuron degeneration and showed only a minimal effect on disease progression. ${ }^{78}$ This study provides no convincing evidence that p53 is involved in cell death in the $\mathrm{G} 3 \mathrm{~A}^{+}$transgenic mouse model of familial ALS. The G93 $\mathrm{A}^{+}$transgenic mouse is modeled on a familial form of ALS linked to the SOD1 gene, which represents only a fraction of familial ALS kindred that account for only 5 to $10 \%$ of all ALS cases. Thus, we cannot rule out the involvement of p53 in other forms of ALS neuropathology. Nonetheless, despite evidence that p53 plays an important role in mediating cell death after acute neuronal injury, there is no definitive evidence to support such a role for p53 in late onset neurodegenerative diseases. It would be of great interest to examine whether p53-deficiency protects neurons and maintains behavioral integrity in $A \beta$ transgenic mice ${ }^{46}$ and in the mouse model of Angelman syndrome..$^{50}$

The role of p53 in excitotoxicity-induced cell death is now generally accepted, although there have been occasional exceptions. In one well-characterized model of excitotoxicity, systemic injection of kainic acid produces seizures associated with a defined pattern of neuronal cell loss and increased p53 expression in neurons exhibiting morphological evidence of damage..$^{36,37}$ Neuronal cell death did not occur when this excitotoxicity model was applied to p53 knock-out mice, demonstrating that p53 induction was causally related to declining viability. ${ }^{79}$ These findings were challenged recently by a report ${ }^{80}$ suggesting that the lack of damage in the p53-deficient mice was attributable to the presence of a protective gene(s) introduced from the C57BL/6 strain used in the generation of the p53 deficient mouse line. ${ }^{4}$ Schauwecker and Steward ${ }^{80}$ reportedly induced comparable seizures in pure C57BL/6 mice and did not see any evidence of neuronal damage in the CA3 or CA1 subregion. In addition, an independent p53-deficient mouse line (on a C57BL/6 $\times 129$ / Sv background ${ }^{81}$ but not on the 129/SvEMS background as cited $^{80}$ ) did not show protection against seizure-induced neuronal cell death as opposed to the significant protection observed in the p53-deficient mice on a 129/SvEv $\times$ C57BL/ 6 background. $^{79}$ The basis for the apparent discrepancy between these reports ${ }^{79,80}$ is not entirely clear.

Although C57BL/6 mice are known to be less susceptible to kainate-induced seizures ${ }^{82,83}$ and seizureinduced damage, ${ }^{84}$ Morrison and collegues ${ }^{79}$ demonstrated significant neuronal damage in the CA3 and CA1 subregions of the hippocampus in p53 wild-type mice (129/SvEv $\times$ C57BL/6 background) despite the genetic contribution from the C57BL/6 strain. Others have also reported significant induction of neuronal damage in the CA3 and CA1 subregions of the hippocampus in C57BL/6 mice in response to kainate-induced seizures. ${ }^{85,86}$ Thus, it is not clear why Schauwecker and Steward failed to 
observe damage at least to the CA3 subregion of C57BL/6 mice in contrast to these other reports. Moreover, despite the contrasting results obtained with the two different p53 knock-out mice, both mouse lines were eventually shown to possess a C57BL/6 genetic background $\left(\mathrm{C} 57 \mathrm{BL} / 6 \times 129 / \mathrm{SvEv}^{4}\right.$ vs $\left.\mathrm{C} 57 \mathrm{BL} / 6 \times 129 / \mathrm{Sv}^{87}\right)$.

It is well recognized that there is a substantial genetic variability among the 129 substrains with documented phenotypic differences. ${ }^{88}$ The variable contribution from the C57BL/ 6 background in the two p53 knock-out mouse strains in combination with other variations in the genetic make-up of the mice used in these experiments make it difficult to draw firm conclusions regarding the role of the purported protective genes in kainic acid-induced neuronal damage seen with one p53 knock-out mouse strain but not the other. Because of such genetic variability, it is conceivable that the excitotoxic insult induced in the p53deficient mouse line on the C57BL/ $6 \times 129 / \mathrm{Sv}$ background $^{80}$ was of such intensity that the resulting cell death was necrotic and independent of any apoptotic signaling pathways. Clearly, there are conditions in which excitatory stimulation can promote neuronal cell death independently of p53 and other cell death mediators. Indeed, Morrison et $a l^{79}$ did report necrotic damage in the CA3 subregion of some p53-deficient mice.

Independent results confirming a role for p53 in excitotoxic cell death comes from studies involving the direct injection of excitatory amino acids into the striatum. Intrastriatally infused kainate produces neuronal death associated with increased p53 levels. Pretreatment with a cell-permeable recombinant peptide targeted to block NF$\kappa \mathrm{B}$ nuclear translocation, inhibits the kainate-induced upregulation of p53 and internucleosomal DNA fragmentation. ${ }^{35}$ These findings suggest that under the appropriate circumstances p53 can promote delayed neuronal cell death observed in response to excitotoxic injury.

Additional evidence to support a role for p53 in excitotoxic cell death will require the application of $p 53$ inhibitors $^{89}$ or antisense oligonucleotides to inhibit p53 activity and suppress p53 expression, respectively. In fact, antisense oligonucleotides can suppress p53 induction and completely inhibit kainate and glutamate-induced cell death in rat cerebellar granule neurons in culture. ${ }^{53}$ Antisense oligonucleotide-mediated p53 suppression also prevents neuronal cell death induced by hypoxia, ${ }^{57}$ DNA damage ${ }^{70}$ and exposure to the HIV gp120 envelope protein. ${ }^{90}$ The adenovirus E1B55K protein has also been used to inhibit p53 function and the resultant sympathetic neuron cell death that ensues from NGF deprivation. ${ }^{58}$ These results demonstrate that $\mathrm{p} 53$ function can be modulated in neurons making it possible to directly evaluate the relationship of p53 to neuronal cell death independently of genetic variations between and within different mouse strains and gene knock-out lines.

\section{Factors regulating p53 expression in response to neuronal injury}

An emerging body of evidence underscores the critical relationship between mitochondrial function, energy bal- ance, and free radical metabolism on the one hand and neuronal viability on the other. ${ }^{91-95}$ Mitochondrial oxidative metabolism, nitric oxide mediated processes, phospholipid metabolism and proteolytic pathways represent potential avenues for the generation of free radicals. The generation of free radicals leads to damage of cellular components such as lipids, proteins and DNA. Accumulation of DNA strand breaks is a well known stimulus for elevating p53 protein levels and for activating p53-mediated signaling pathways. $^{32,33}$ lonizing radiation causes DNA damage and is associated with elevated p53 protein levels in neurons. ${ }^{34,56}$ The ataxia telangiectasia (ATM) gene, whose mutation is associated with a neurodegenerative syndrome, is required for p53 activation and neuronal cell death in response to irradiation. ${ }^{34,96}$ Developing mice lacking the ATM gene are resistant to ionizing radiation and show a significant reduction in p53 accumulation in several brain regions following irradiation. ${ }^{34}$ However, the extent of apoptosis in the cerebellum of irradiated ATM-deficient mice is more pronounced than that in p53-deficient mice. ${ }^{96}$ While these studies demonstrate that the ATM gene is upstream of p53, it also suggests that there may be additional signaling pathways regulating p53-dependent processes.

The stress activated kinases, particularly the Jun Nterminal kinase (JNK) and the p38 MAP kinase are activated in response to genotoxic damage ${ }^{97,98}$ and both have been shown to phosphorylate the p53 protein. $^{99-101}$ Direct stimulation of the JNK pathway in sympathetic neurons elevates p53 protein levels and induces neuronal cell death. ${ }^{58}$ In contrast, nerve growth factor promotes neuronal survival by binding to and activating the TrkA receptor, which, in turn, stimulates several signaling pathways including the small GTP-binding protein p21 Ras (Ras). Ras activates several downstream effector proteins, including Raf and phosphatidylinositol 3-kinase (PI3-K). Raf binds to and activates the MAP kinase kinase 1 (MEK1) and MEK2 signaling cascade, culminating in the activation of the extracellular signal-regulated kinase (ERK). Thus, the ERK pathway, which can act in direct opposition to JNK and p38 MAP kinases, ${ }^{102}$ has been shown to protect against p53-mediated cell death in sympathetic neurons. ${ }^{55} \mathrm{PI3}-\mathrm{K}$ activates the serine/threonine kinase Akt (protein kinase B), which stimulates neuronal survival ${ }^{103,104}$ in part, through the inactivation of BAD. ${ }^{105}$ Phosphorylated BAD is sequestered by the 14-3-3 protein releasing $\mathrm{Bclx}_{\mathrm{L}}$ to antagonize Bax. ${ }^{106}$ The direct activation of Ras, which sits upstream of ERK, is sufficient to suppress a p53-mediated cell death pathway in sympathetic neurons. ${ }^{107}$ Ras may inhibit p53-mediated apoptosis by suppressing p53 and bax protein levels, and Bax activity, the latter playing a key role in developmental cell death in sympathetic neurons. ${ }^{108}$

$\mathrm{NF}-\kappa \mathrm{B}$ is an essential survival factor in several physiological conditions, but it is also a main mediator of the cellular response to a variety of extracellular stress stimuli resulting in apoptosis. Intrastriatal administration of the excitatory receptor agonists, quinolinic acid or kainic acid, induces NF- $\kappa \mathrm{B}$ nuclear translocation and increased cmyc and p53 mRNA and protein expression in striatal 
neurons undergoing apoptosis. ${ }^{35,38}$ The addition of an NF$\kappa \mathrm{B}$ targeted cell-permeable recombinant peptide blocks NF$\kappa \mathrm{B}$ nuclear translocation and the elevation in c-myc and p53 mRNA and protein expression. These effects were associated with a significant reduction in neuronal cell death, suggesting that the transcription factor $\mathrm{NF}-\kappa \mathrm{B}$ may promote neuronal apoptosis by regulating the expression of p53. Interestingly, p53 induction has been reported to cause an activation of NF- $\kappa \mathrm{B}$ that correlates with the ability of p53 to induce apoptosis. ${ }^{109}$ Thus, once induced, p53 may ensure its continued expression by activating NF- $\kappa \mathrm{B}$.

Several other unrelated molecules modulate p53 expression. These include the cations lithium and magnesium. Lithium, which has been used to treat bipolar depressive disease, protects neurons from cell death induced by middle cerebral artery occlusion, ${ }^{110}$ an insult that increases p53 expression. ${ }^{42,43}$ More recently, lithium has been shown to suppress glutamate-induced increases in p53 and Bax protein levels in cultured cerebellar granule neurons. ${ }^{54}$ Administration of magnesium is neuroprotective in experimental models of traumatic brain injury. Recent evidence suggests that the neuroprotective effects of magnesium treatment may be related, in part, to downregulation of p53 gene expression. ${ }^{41}$ The mechanisms underlying the suppression of p53 expression by lithium and magnesium have not been identified.

A novel and potentially physiologically relevant p53 regulatory pathway has recently been described for the human amyloid precursor protein (APP). Wild-type human APP was shown to prevent cell death in a differentiated neuronal cell line in response to elevated p53 expression induced by UV irradiation, staurosporine treatment and p53-adenovirus infection. ${ }^{111}$ Mutant forms of APP associated with familial-early onset forms of Alzheimer's disease did not confer protection. While neither form of APP altered p53 protein levels or p53 nuclear translocation, wild-type APP, in contrast to mutant APP, suppressed p53-mediated transcriptional activation from a p53-responsive promoter. The mechanism by which APP-mediated signaling altered p53 activation was not identified. However, this result suggests that naturally occurring mutations in genes predisposing individuals to neurodegeneration could enhance neuronal vulnerability to p53-mediated cell death in response to secondary insults.

In summary, these results demonstrate that: (1) p53 expression is upregulated in neurons in response to a diverse array of cellular insults, (e.g., excitotoxicity, hypoxia, ionizing irradiation, trophic factor depletion, etc.); (2) p53 expression is regulated by discrete signal transduction pathways; and (3) knowledge of these signaling pathways can be used to manipulate p53 expression in order to suppress p53-mediated cell death in neurons.

\section{Mechanism of p53-mediated cell death in neurons}

p53 promotes apoptosis by modulating the expression of select target genes. The p53 protein can function as a sitespecific transactivator or a repressor of transcription. ${ }^{18,112-115}$
Numerous pro-apoptotic genes are susceptible to regulation by p53 including Bax, ${ }^{116}$ IGF-binding protein-3, ${ }^{117}$ Fas, ${ }^{118,119}$ the p53-inducible genes (PIG's) ${ }^{120}$ and reaper. ${ }^{121}$ p53 may also induce apoptosis through transcriptional repression although the mechanism for repression is not understood. Genes downregulated by $\mathrm{p} 53$ include bcl- $2,{ }^{19}$ the IGF-I receptor, ${ }^{122}$ the microtubule associated protein MAP $4{ }^{123}$ and presenilin-1. ${ }^{20}$ An important finding has recently suggested that p53 may promote cell death by altering the expression of enzymes that regulate the redox state of cells. ${ }^{120}$ Therefore, one intriguing possibility is that p53-induced changes in cell viability may stem, in part, from alterations in free radical metabolism and declining mitochondrial function. ${ }^{124}$ Disruption of the mitochondrial membrane potential and increased production of reactive oxygen species have been defined as early events in the process of neuronal apoptosis. ${ }^{93,125-128}$

The mechanism by which p53 specifies the neuronal response to injury is poorly understood. However, the few studies published to date utilizing neurons are in agreement with the idea that Bcl-2 family member, Bax, is essential for p53-mediated cell death in neurons. Baxdeficient neurons are protected from cell death induced by DNA damaging agents ${ }^{69,96}$ and adenovirus-mediated p53 over-expression. ${ }^{69,129}$ One possibility is that p53-induced changes in neuronal viability stem from declining mitochondrial function initiated by alterations in the activity of Bax. This hypothesis is consistent with the demonstration that mitochondrial dysfunction, detected as the loss of mitochondrial membrane potential and increased production of reactive oxygen species, plays an obligate role in certain forms of neuronal damage. ${ }^{27-30}$ A relationship between Bax and alterations in mitochondrial function is substantiated by the recent demonstration that cell damage promotes Bax translocation from the cytosol to the mitochondria in COS cells ${ }^{130-132}$ and in neurons. ${ }^{133,134}$ Bax activation has been associated with a reduction in mitochondrial membrane potential, mitochondrial release of cytochrome $c$ and activation of caspases. ${ }^{135-139}$ This suggests that caspases may also be a component of the p53-induced cell death pathway sitting downstream of Bax activation.

The relationship between p53 and caspase activation has recently been examined in neurons. Recent studies indeed demonstrated that p53 is required for caspase activation in response to genotoxic stress. ${ }^{69,96,129,140}$ These findings suggest that some forms of neuronal injury invoke a common pathway involving signal transduction through p53, Bax, mitochondrial dysfunction, cytochrome c release and caspase activation. However, other forms of injury have been shown to induce neuronal cell death by stimulating Bax translocation and caspase activation independently of p53. ${ }^{141}$ These results demonstrate that different cellular stresses can elicit cell death by activating distinct signaling pathways culminating in Bax and caspase activation.

Caspase activation can thus be regulated by both p53dependent and p53-independent pathways, depending upon the nature of the injury stimulus. When activated in response to a p53-dependent pathway the contribution of caspases to cell death is controversial. Caspase-3 
activation is required for p53-dependent cell death in cerebellar granule neurons in response to ionizing radiation $^{96}$ consistent with results obtained in nonneuronal cells. ${ }^{139,142-144}$ However, specific peptide inhibitors of caspases (zVAD-fmk, zDEVD-fmk and BAF) did not protect hippocampal and cortical neurons from p53-dependent cell death induced by radiation, ${ }^{71}$ glutamate $^{72}$ or camptothecin-treatment ${ }^{140}$ when the neuronal cultures were established from postnatal animals as opposed to embryos. In addition, adenovirus-mediated overexpression of p53 promoted neuronal cell death but did not induce caspase activity in postnatal cortical neurons. ${ }^{140}$ Moreover, adenovirus-mediated p53 gene delivery to caspase-3 deficient postnatal cerebellar granule neurons demonstrated a delay but not complete protection from cell death. ${ }^{129}$ These results are consistent with reports supporting the existence of caspaseindependent mechanisms of programmed cell death in other cell types ${ }^{135,145-147}$ and suggest that the requirement for caspase activity depends on the developmental status of neurons.

Clearly, additional studies are required to elucidate the downstream effectors mediating neuronal cell death in response to p53 activation. The glyceraldehyde-3-phosphate dehydrogenase (GAPDH) gene has been identified as a p53-inducible gene in cultured cerebellar granule

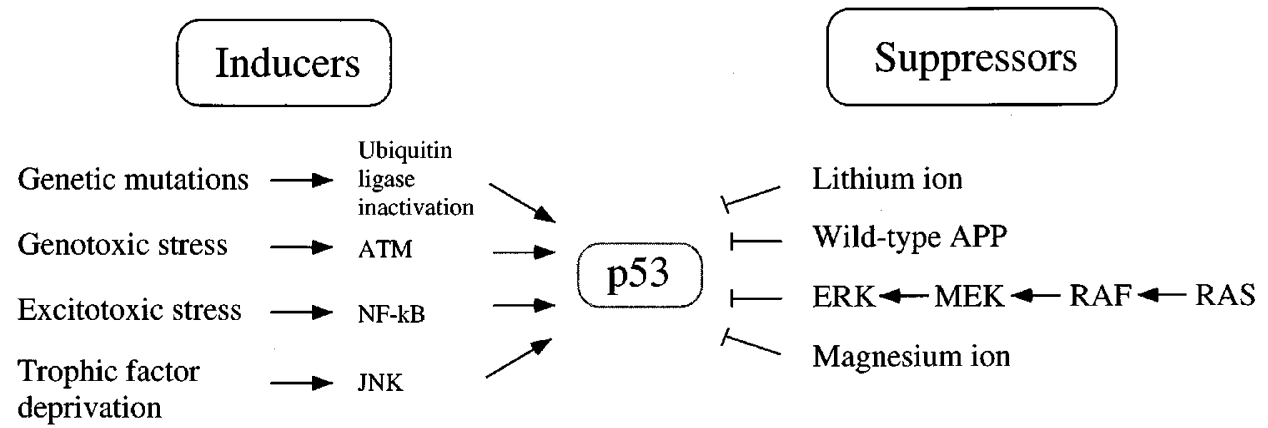

Figure 1 Schematic representation of proposed inducers and suppressors of p53 expression and p53-mediated cell death in neurons. Specific cellular insults such as genotoxic and excitotoxic stresses are shown in relation to the specific signal transduction cascades they activate upstream of p53. An inactivating mutation in the E6-AP ubiquitin ligase, in a mouse model of Angelman's syndrome, has been associated with increased cytoplasmic abundance of the p53 protein, ${ }^{50}$ consistent with the demonstration that $p 53$ protein levels are normally regulated through a ubiquitin-dependent, proteasome-mediated pathway. ${ }^{10,11}$ The mechanisms by which the various suppressors limit p53 expression or function following injury have not been identified with the exception of the RAS $\rightarrow$ ERK pathway. ATM, ataxia telangiectasia gene; JNK, c-Jun-N-terminal kinase; APP, amyloid precursor protein; ERK, extracellular signal regulated kinase; MEK, mitogen activated protein kinase kinase

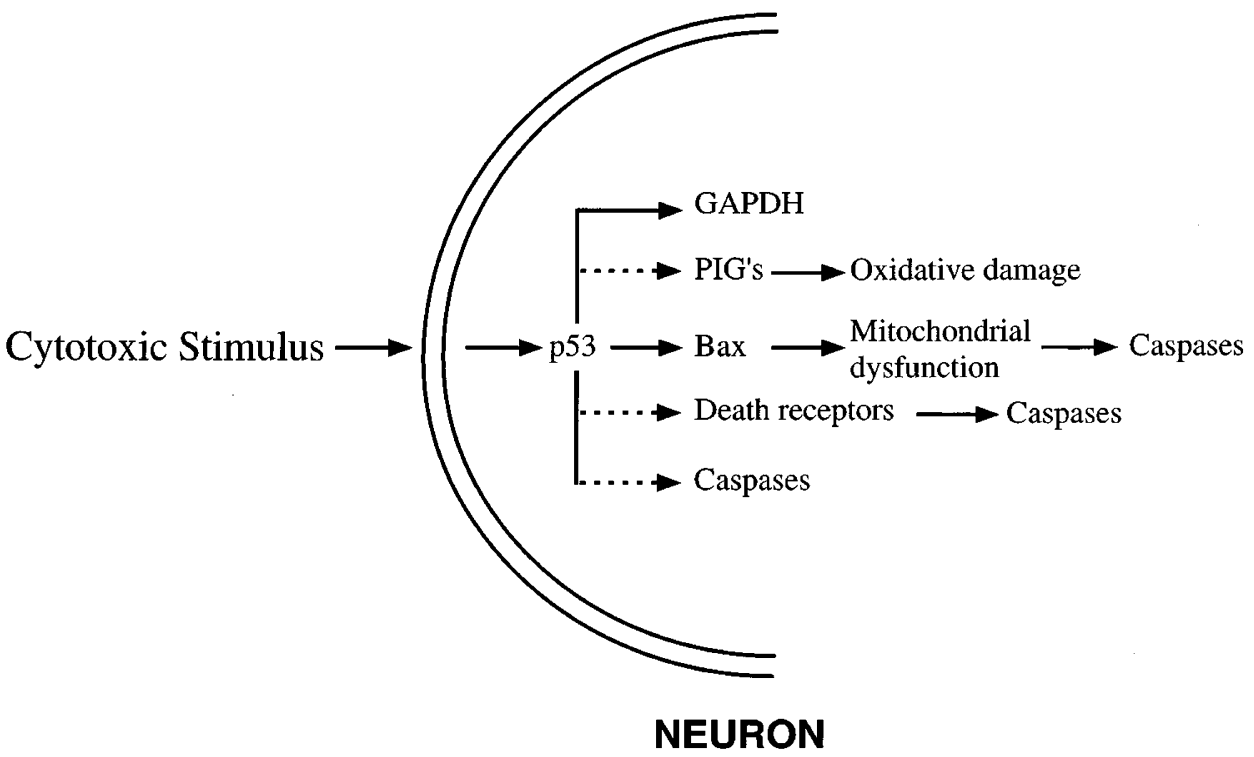

Figure 2 Schematic representation of cell death effectors activated in response to p53 induction. Various cytotoxic insults lead to the activation of p53 (as shown in Figure 1), which, in turn, activates several downstream effectors. Those pathways clearly associated with p53 dependent cell death in neurons are marked by solid arrows. Those pathways that have been associated with p53-dependent cell death in non-neuronal cells are marked by broken arrows. Clearly, many of the p53-dependent downstream effectors identified in non-neuronal cells should be evaluated in neurons. Caspases are listed in relation to several distinct pathways because evidence demonstrates that they are activated in response to: (1) mitochondrial damage and cytochrome $c$ release; (2) the activation of death receptors such as TNF receptor and Fas (CD95); and (3) direct protein-protein interactions with p53. ${ }^{21}$ GAPDH, glyceraldehyde-3-phosphate dehydrogenase; PIG's, p53inducible genes 
neurons subject to DNA damage. ${ }^{70}$ Antisense oligonucleotide-mediated suppression of GAPDH expression is neuroprotective, ${ }^{148}$ suggesting that GAPDH may function as a p53 cell death effector. However, the precise mechanism underlying the involvement of GAPDH in neuronal apoptosis is unclear. Other genes, such as DR5, Fas, Fas ligand ${ }^{18}$ and PERP ${ }^{149}$ have been shown to be induced by apoptotic stimuli as a result of p53 activation in a variety of non-neuronal cell types, but the involvement of these genes in p53-dependent neuronal apoptosis is not known.

\section{Summary}

Emerging evidence obtained from acute injury models and brain tissue derived from patients with chronic neurodegenerative diseases implicate the p53 tumor suppressor protein in the regulation of neuronal cell death. The presence of p53 in damaged neurons, which often suffer significant oxidative stress following injury, is consistent with p53's known role in responding to a variety of stimuli, including oxidative stress, chemotherapeutic agents, hypoxia, nucleotide depletion, and oncogene expression. ${ }^{114,150}$ Many unanswered questions remain regarding the role of p53 in neurons. For example, does p53 normally play a role in maintaining DNA integrity in neurons by regulating DNA repair processes in the absence of injury? How p53 induces neuronal cell death remains unresolved. The full gamut of genes activated or repressed in neurons in response to p53 induction have not been identified. In this regard, gene expression studies involving serial analysis of gene expression (SAGE) and cDNA microarray analysis will help to identify genes that are differentially expressed in response to p53 induction, ${ }^{151}$ further defining the mechanisms underlying p53-dependent cell death in neurons. Characterizing the involvement of recently identified p53 family members in neuronal cell death will also contribute to the current understanding of the p53 pathway. All three proteins (p53, p63 and p73) share similar transcriptional activities as well as the ability to induce apoptosis. ${ }^{152,153}$ However, each appears to play a distinct role in development and tumor suppression. ${ }^{152,153}$ Additional evidence in support of a direct role for p53 in neuronal apoptosis will eventually be provided by the application of chemical inhibitors of $\mathrm{p} 53,{ }^{89}$ which may be utilized to transiently suppress p53-mediated cell death pathways in acutely injured neurons. The continuing development of new information concerning p53-dependent neuronal cell death is encouraging, as this knowledge may ultimately be translated into effective treatments for maintaining neuronal viability and restoring function following cytopathic insults to the nervous system.

\section{Note added in proof}

After submission of this manuscript, two papers have appeared that are relevant to this review. Pozniak et al. (Science 289:304-306) have demonstrated in vivo and in vitro that an amino terminal-truncated form of p73 functions as a p53 antagonist, preventing p53-mediated developmental death of sympathetic neurons in response to NGF deprivation.
Steffan et al. (Proc. Natl. Acad. Sci. USA 91:9842-9846) have shown that the Huntington's disease protein, huntingtin, interacts with p53 and CBP affecting p53-dependent gene transcription, providing another example of p53's potential contribution to neurodegenerative diseases.

\section{Acknowledgments}

We gratefully acknowledge Dr. Philip Schwartzkroin, Dr. Abel Jarell and Joseph $\mathrm{T}$ Ho for reviewing the manuscript. This work was supported in part by a grant from the National Institutes of Health NS31775 to RS Morrison.

\section{References}

1. Greenblatt MS, Bennett WP, Hollstein M and Harris CC (1994) Mutations in the p53 tumor suppressor gene: clues to cancer etiology and molecular pathogenesis. Cancer Res. 54: 4855-4878

2. Malkin D, LiFP, Strong LC, FraumeniJrJF, Nelson CE, Kim DH, Kassel J, Gryka MA, BischoffFZ, Tainsky MA and Friend SH (1990) Germ line p53 mutations in a familial syndrome of breast cancer, sarcomas, and other neoplasms. Science 250: $1233-1238$

3. Srivastava S, Zou ZQ, Pirollo K, Blattner W and Chang EH (1990) Germ-line transmission of a mutated p53 gene in a cancer-prone family with Li-Fraumeni syndrome. Nature 348: 747-749

4. DonehowerLA, Harvey M, SlagleBL, McArthurMJ, Montgomery JrCA, ButelJS and Bradley $A$ (1992) Mice deficient for p53 are developmentally normal but susceptible to spontaneous tumours. Nature 356: 215-221

5. Harvey M, McArthur MJ, Montgomery Jr CA, Butel JS, Bradley A and Donehower LA (1993) Spontaneous and carcinogen-induced tumorigenesis in p53-deficient mice. Nat. Genet. 5: 225-229

6. Jacks T, Remington L, Williams BO, Schmitt EM, Halachmi S, Bronson RT and Weinberg RA (1994) Tumor spectrum analysis in p53-mutant mice. Curr. Biol. 4: $1-7$

7. Purdie CA, Harrison DJ, Peter A, Dobbie L, White S, Howie SE, Salter DM, Bird CC, Wyllie AH, Hooper ML and Clarke AR (1994) Tumour incidence, spectrum and ploidy in mice with a large deletion in the p53 gene. Oncogene 9: 603-609

8. Ko LJ and Prives C (1996) p53: puzzle and paradigm. Genes Dev. 10: $1054-$ 1072

9. Giaccia AJ and Kastan MB (1998) The complexity of p53 modulation: emerging patterns from divergent signals. Genes Dev. 12: 2973-2983

10. Haupt Y, Maya R, Kazaz A and Oren M (1997) Mdm2 promotes the rapid degradation of p53. Nature 387: 296-299

11. Kubbutat MH, Jones SN and Vousden KH (1997) Regulation of p53 stability by Mdm2. Nature 387: 299-303

12. Shieh SY, Ikeda M, Taya $Y$ and Prives C (1997) DNA damage-induced phosphorylation of $p 53$ alleviates inhibition by MDM2. Cell 91: 325-334

13. Unger T, Juven-Gershon T, Moallem E, Berger M, Vogt Sionov R, Lozano G, Oren M and Haupt $Y$ (1999) Critical role for Ser20 of human p53 in the negative regulation of $\mathrm{p} 53$ by Mdm2. EMBO J. 18: 1805-1814

14. Kamijo T, Weber JD, Zambetti G, Zindy F, Roussel MF and Sherr CJ (1998) Functional and physical interactions of the ARF tumor suppressor with $p 53$ and Mdm2. Proc. Natl. Acad. Sci. U.S.A. 95: 8292-8297

15. Pomerantz J, Schreiber-Agus N, Leigeois NJ, Silverman A, Alland L, Chin L, Potes J, Chen K, Orlow I, Lee HW, Cordon-Cardo C and DePinho RA (1998) The Ink4a tumor suppressor gene product, p19Arf, interacts with MDM2 and neutralizes MDM2's inhibition of p53. Cell 92: 713-723

16. Bates S, Phillips AC, Clark PA, Stott F, Peters G, Ludwig RL and Vousden KH (1998) p14ARF links the tumour suppressors RB and p53. Nature 395: $124-$ 125

17. Bates S and Vousden KH (1996) p53 in signaling checkpoint arrest or apoptosis. Curr. Opin. Genet. Dev. 6: 12-18

18. Asker C, Wiman KG and Selivanova G (1999) p53-induced apoptosis as a safeguard against cancer. Biochem. Biophys. Res. Commun. 265: 1-6 
19. Miyashita T, Harigai M, Hanada M and Reed JC (1994) Identification of a p53 dependent negative response element in the bcl-2 gene. Cancer Res. 54 $3131-3135$

20. Roperch JP, Alvaro V, Prieur S, Tuynder M, Nemani M, Lethrosne F, Piouffre L, Gendron MC, Israeli D, Dausset J, Oren M, Amson R and Telerman A (1998) Inhibition of presenilin 1 expression is promoted by p53 and p21WAF-1 and results in apoptosis and tumor suppression. Nat. Med. 4: 835-838

21. Ding HF, McGill G, Rowan S, Schmaltz C, Shimamura A and Fisher DE (1998) Oncogene-dependent regulation of caspase activation by $p 53$ protein in a cellfree system. J. Biol. Chem. 273: 28378-28383

22. Gottlieb E and Oren M (1998) p53 facilitates pRb cleavage in IL-3-deprived cells: novel pro-apoptotic activity of p53. EMBO J. 17: 3587-3596

23. Raff MC, Barres BA, Burne JF, Coles HS, Ishizaki Y and Jacobson MD (1993) Programmed cell death and the control of cell survival: lessons from the nervous system. Science 262: $695-700$

24. Stefanis L, Burke RE and Greene LA (1997) Apoptosis in neurodegenerative disorders. Curr. Opin. Neurol. 10: 299-305

25. Friedlander RM and Yuan J (1998) ICE, neuronal apoptosis and neurodegeneration. Cell Death Differ. 5: 823-831

26. Tatton WG and Olanow CW (1999) Apoptosis in neurodegenerative diseases: the role of mitochondria. Biochim. Biophys. Acta 1410: 195-213

27. Ankarcrona M, Dypbukt JM, Bonfoco E, Zhivotovsky B, Orrenius S, Lipton SA and Nicotera $P$ (1995) Glutamate-induced neuronal death: a succession of necrosis or apoptosis depending on mitochondrial function. Neuron 15: $961-$ 973

28. Dugan LL, Sensi SL, Canzoniero LM, Handran SD, Rothman SM, Lin TS, Goldberg MP and Choi DW (1995) Mitochondrial production of reactive oxygen species in cortical neurons following exposure to $\mathrm{N}$-methyl-D-aspartate. J. Neurosci. 15: 6377-6388

29. Reynolds IJ and Hastings TG (1995) Glutamate induces the production of reactive oxygen species in cultured forebrain neurons following NMDA receptor activation. J. Neurosci. 15: 3318-3327

30. Schinder AF, Olson EC, Spitzer NC and Montal M (1996) Mitochondrial dysfunction is a primary event in glutamate neurotoxicity. J. Neurosci. 16: 6125-6133

31. Didier M, Bursztajn S, Adamec E, Passani L, Nixon RA, Coyle JT, Wei JY and Berman SA (1996) DNA strand breaks induced by sustained glutamate excitotoxicity in primary neuronal cultures. J. Neurosci. 16: 2238-2250

32. Jayaraman $\mathrm{J}$ and Prives $\mathrm{C}$ (1995) Activation of p53 sequence-specific DNA binding by short single strands of DNA requires the p53 C-terminus. Cell 81: 1021-1029

33. Huang LC, Clarkin KC and Wahl GM (1996) Sensitivity and selectivity of the DNA damage sensor responsible for activating p53-dependent $\mathrm{G} 1$ arrest. Proc. Natl. Acad. Sci. U.S.A. 93: 4827-4832

34. Herzog KH, Chong MJ, Kapsetaki M, Morgan JI and McKinnon PJ (1998) Requirement for Atm in ionizing radiation-induced cell death in the developing central nervous system. Science 280: 1089-1091

35. Nakai M, Qin ZH, Chen JF, Wang Y and Chase TN (2000) Kainic acid-induced apoptosis in rat striatum is associated with nuclear factor-kappaB activation. J. Neurochem. 74: 647-658

36. Sakhi S, Bruce A, Sun N, Tocco G, Baudry M and Schreiber SS (1994) p53 induction is associated with neuronal damage in the central nervous system. Proc. Natl. Acad. Sci. U.S.A. 91: 7525-7529

37. Sakhi S, Sun N, Wing LL, Mehta P and Schreiber SS (1996) Nuclear accumulation of p53 protein following kainic acid-induced seizures. NeuroReport 7: 493-496

38. Qin ZH, Chen RW, Wang Y, Nakai M, Chuang DM and Chase TN (1999) Nuclear factor kappaB nuclear translocation upregulates c-Myc and p53 expression during NMDA receptor-mediated apoptosis in rat striatum. J. Neurosci. 19: 4023-4033

39. Wang Y, Qin ZH, Nakai M, Chen RW, Chuang DM and Chase TN (1999) Costimulation of cyclic-AMP-linked metabotropic glutamate receptors in rat striatum attenuates excitotoxin-induced nuclear factor-kappaB activation and apoptosis. Neuroscience 94: 1153-1162

40. Napieralski JA, Raghupathi R and McIntosh TK (1999) The tumor-suppressor gene, $\mathrm{p53}$, is induced in injured brain regions following experimental traumatic brain injury. Brain Res. Mol. Brain Res. 71: 78-86
41. Muir JK, Raghupathi R, Emery DL, Bareyre FM and Mclntosh TK (1999) Postinjury magnesium treatment attenuates traumatic brain injury- induced cortical induction of p53 mRNA in rats. Exp. Neurol. 159: 584-593

42. Chopp M, Li Y, Zhang ZG and Freytag SO (1992) p53 expression in brain after middle cerebral artery occlusion in the rat. Biochem. Biophys. Res. Commun. 182: $1201-1207$

43. Watanabe H, Ohta S, Kumon Y, Sakaki S and Sakanaka M (1999) Increase in p53 protein expression following cortical infarction in the spontaneously hypertensive rat. Brain Res. 837: 38-45

44. de la Monte SM, Sohn YK and Wands JR (1997) Correlates of p53- and Fas (CD95)-mediated apoptosis in Alzheimer's disease. J. Neurol. Sci. 152: 73-83

45. de la Monte SM, Sohn YK, Ganju N and Wands JR (1998) P53- and CD95associated apoptosis in neurodegenerative diseases. Lab. Invest. 78: 401411

46. LaFerla FM, Hall CK, Ngo L and Jay G (1996) Extracellular deposition of betaamyloid upon p53-dependent neuronal cell death in transgenic mice. J. Clin. Invest. 98: 1626-1632

47. Citron M, Oltersdorf T, Haas C, McConlogue L, Hung AY, Seubert P, VigoPelfrey C, Lieberburg I and Selkoe DJ (1992) Mutation of the beta-amyloid precursor protein in familial Alzheimer's disease increases beta-protein production. Nature 360: 672-674

48. Shoji M, Golde TE, Ghiso J, Cheung TT, Estus S, Shaffer LM, Cai XD, McKay DM, Tintner R, Frangione B and Younkin SG (1992) Production of the Alzheimer amyloid beta protein by normal proteolytic processing. Science 258: $126-129$

49. Busciglio J, Gabuzda DH, Matsudaira P and Yankner BA (1993) Generation of beta-amyloid in the secretory pathway in neuronal and nonneuronal cells. Proc. Natl. Acad. Sci. U.S.A. 90: 2092-2096

50. Jiang YH, Armstrong D, Albrecht U, Atkins CM, Noebels JL, Eichele G, Sweatt JA and Beaudet AL (1998) Mutation of the Angelman ubiquitin ligase in mice causes increased cytoplasmic $p 53$ and deficits of contextual learning and longterm potentiation. Neuron 21: 799-811

51. Sawa A (1999) Neuronal cell death in Down's syndrome. J. Neural Transm. Suppl. 57: $87-97$

52. Seidl R, Fang-Kircher S, Bidmon B, Cairns N and Lubec G (1999) Apoptosisassociated proteins $\mathrm{p} 53$ and APO-1/Fas (CD95) in brains of adult patients with Down syndrome. Neurosci. Lett. 260: $9-12$

53. Uberti D, Belloni M, Grilli M, Spano P and Memo M (1998) Induction of tumoursuppressor phosphoprotein p53 in the apoptosis of cultured rat cerebellar neurones triggered by excitatory amino acids. Eur. J. Neurosci. 10: 246-254

54. Chen RW and Chuang DM (1999) Long term lithium treatment suppresses p53 and Bax expression but increases Bcl-2 expression. A prominent role in neuroprotection against excitotoxicity. J. Biol. Chem. 274: 6039-6042

55. Anderson CNG and Tolkovsky AM (1999) A role for MAPK/ERK in sympathetic neuron survival: protection against a p53-dependent, JNK-independent induction of apoptosis by cytosine arabinoside. J. Neurosci. 19: 664-673

56. Jordan J, Galindo MF, Prehn JH, Weichselbaum RR, Beckett M, Ghadge GD, Roos RP, Leiden JM and Miller RJ (1997) p53 expression induces apoptosis in hippocampal pyramidal neuron cultures. J. Neurosci. 17: 1397-1405

57. Banasiak KJ and Haddad GG (1998) Hypoxia-induced apoptosis: effect of hypoxic severity and role of p53 in neuronal cell death. Brain Res. 797: 295304

58. Aloyz RS, Bamji SX, Pozniak CD, Toma JG, Atwal J, Kaplan DR and Miller FD (1998) p53 is essential for developmental neuron death as regulated by the TrkA and p75 neurotrophin receptors. J. Cell Biol. 143: 1691-1703

59. Crumrine RC, Thomas AL and Morgan PF (1994) Attenuation of p53 expression protects against focal ischemic damage in transgenic mice. J. Cereb. Blood Flow Metab. 14: 887-891

60. Wood KA and Youle RJ (1995) The role of free radicals and p53 in neuron apoptosis in vivo. J. Neurosci. 15: 5851-5857

61. Trimmer PA, Smith TS, Jung AB and Bennett Jr JP (1996) Dopamine neurons from transgenic mice with a knockout of the 553 gene resist MPTP neurotoxicity. Neurodegeneration 5: 233-239

62. Hirata Hand CadetJL (1997) p53-knockout mice are protected against the longterm effects of methamphetamine on dopaminergic terminals and cell bodies. J. Neurochem. 69: 780-790 
63. Sakhi S, Gilmore W, Tran ND and Schreiber SS (1996) p53-deficient mice are protected against adrenalectomy-induced apoptosis. NeuroReport 8: 233235

64. Lee EY, Chang CY, Hu N, Wang YC, Lai CC, Herrup K, Lee WH and Bradley A (1992) Mice deficient for $\mathrm{Rb}$ are nonviable and show defects in neurogenesis and haematopoiesis. Nature 359: 288-294

65. Macleod KF, Hu Y and Jacks T (1996) Loss of Rb activates both p53-dependent and independent cell death pathways in the developing mouse nervous system. EMBO J. 15: 6178-6188

66. Enokido Y, Araki T, Tanaka K, Aizawa S and Hatanaka H (1996) Involvement of p53 in DNA strand break-induced apoptosis in postmitotic CNS neurons. Eur. J. Neurosci. 8: 1812-1821

67. Enokido Y, Araki T, Aizawa S and Hatanaka H (1996) p53 involves cytosine arabinoside-induced apoptosis in cultured cerebellar granule neurons. Neurosci. Lett. 203: 1-4

68. Araki T, Enokido Y, Inamura N, Aizawa S, Reed JC and Hatanaka H (1998) Changes in c-Jun but not Bcl-2 family proteins in p53-dependent apoptosis of mouse cerebellar granule neurons induced by DNA damaging agent bleomycin. Brain Res. 794: 239-247

69. Xiang H, Kinoshita Y, Knudson CM, Korsmeyer SJ, Schwartzkroin PA and Morrison RS (1998) Bax involvement in p53-mediated neuronal cell death. J. Neurosci. 18: 1363-1373

70. Chen RW, Saunders PA, Wei H, Li Z, Seth P and Chuang DM (1999) Involvement of glyceraldehyde-3-phosphate dehydrogenase (GAPDH) and p53 in neuronal apoptosis: evidence that GAPDH is upregulated by p53. J. Neurosci. 19: 9654-9662

71. Johnson MD, Xiang H, London S, Kinoshita Y, Knudson M, Mayberg M, Korsmeyer SJ and Morrison RS (1998) Evidence for involvement of Bax and p53, but not caspases, in radiation-induced cell death of cultured postnatal hippocampal neurons. J. Neurosci. Res. 54: 721-733

72. Xiang H, Hochman DW, Saya H, Fujiwara T, Schwartzkroin PA and Morrison RS (1996) Evidence forp53-mediated modulation of neuronal viability. J. Neurosci. 16: $6753-6765$

73. Halterman MW, Miller CC and Federoff HJ (1999) Hypoxia-inducible factoralpha mediates hypoxia-induced delayed neuronal death that involves p53. J. Neurosci. 19: 6818-6824

74. Vogel KS and Parada LF (1998) Sympathetic neuron survival and proliferation are prolonged by loss of $p 53$ and neurofibromin. Mol. Cell. Neurosci. 11:19-28

75. Gurney ME, Pu H, Chiu AY, Dal Canto MC, Polchow CY, Alexander DD, Caliendo J, Hentati A, Kwon YW, Deng H-X, Chen W, Zhai P, Surfit RL and Siddique T (1994) Motorneuron degeneration in mice that express a human Cu, Zn superoxide dismutase mutation. Science 264: 1772-1775

76. Ripps ME, Huntley GW, Hof PR, Morrison JH and Gordon JW (1995) Transgenic mice expressing an altered murine superoxide dismutase gene provide an animal model of amyotrophic lateral sclerosis. Proc. Natl. Acad. Sci. U.S.A. 92 $689-693$

77. Bruijn LI, Becher MW, Lee MK, Anderson KL, Jenkins NA, Copeland NG, Sisodia SS, Rothstein JD, Borchelt DR, Price DL and Cleveland DW (1997) ALS-linked SOD1 mutant G85R mediates damage to astrocytes and promotes rapidly progressive disease with SOD1-containing inclusions. Neuron 18 $327-338$

78. Kuntz C, Kinoshita Y, Beal F, Donehower LA and Morrison RS (2000) The absence of p53 does not protect SOD1 mutant mice from onset of clinical symptoms or lethality. Exp. Neurol. (In Press)

79. Morrison RS, Wenzel HJ, Kinoshita Y, Robbins CA, Donehower LA and Schwartzkroin PA (1996) Loss of the p53 tumor suppressor gene protects neurons from kainate-induced cell death. J. Neurosci. 16: 1337-1345

80. Schauwecker PE and Steward O (1997) Genetic determinants of susceptibility to excitotoxic cell death: implications for gene targeting approaches. Proc. Natl. Acad. Sci. U.S.A. 94: 4103-4108

81. Lowe SW, Schmitt EM, Smith SW, Osborne BA and Jacks T (1993) p53 is required for radiation-induced apoptosis in mouse thymocytes. Nature 362 847-849

82. Engstrom FL and Woodbury DM (1988) Seizure susceptibility in DBA and C57 mice: the effects of various convulsants. Epilepsia 29: 389-395

83. Ferraro TN, Golden GT, Smith GG and Berrettini WH (1995) Differential susceptibility to seizures induced by systemic kainic acid treatment in mature DBA/2J and C57BL/6J mice. Epilepsia 36: 301-307
84. Royle SJ, Collins FC, Rupniak HT, Barnes JC and Anderson R (1999) Behavioural analysis and susceptibility to CNS injury of four inbred strains of mice. Brain Res. 816: 337-349

85. Hu RQ, Koh S, Torgerson T and Cole AJ (1998) Neuronal stress and injury in C57/BL mice after systemic kainic acid administration. Brain Res. 810: 229 240

86. Hertel M, Tretter Y, Alzheimer C and Werner S (2000) Connective tissue growth factor: a novel player in tissue reorganization after brain injury? Eur. J. Neurosci. 12: 376-380

87. Livingstone LR, White A, Sprouse J, Livanos E, Jacks T and TIsty TD (1992) Altered cell cycle arrest and gene amplification potential accompany loss of wild-type p53. Cell 70: 923-935

88. Simpson EM, Linder CC, Sargent EE, Davisson MT, Mobraaten LE and Sharp JJ (1997) Genetic variation among 129 substrains and its importance for targeted mutagenesis in mice. Nat. Genet. 16: 19-27

89. Komarov PG, Komarova EA, Kondratov RV, Christov-Tselkov K, Coon JS, Chernov MV and Gudkov AV (1999) A chemical inhibitor of p53 that protects mice from the side effects of cancer therapy. Science 285: 1733-1737

90. Yeung MC, Geertsma F, Liu J and Lau AS (1998) Inhibition of HIV-1 gp120induced apoptosis in neuroblastoma SK-N-SH cells by an antisense oligodeoxynucleotide against p53. AIDS 12: 349-354

91. Beal MF (1995) Aging, energy, and oxidative stress in neurodegenerative diseases. Ann. Neurol. 38: 357-366

92. Schulz JB, Matthews RT and Beal MF (1995) Role of nitric oxide in neurodegenerative diseases. Curr. Opin. Neurol. 8: 480-486

93. Marchetti P, Castedo M, Susin SA, Zamzami N, Hirsch T, Macho A, Haeffner A Hirsch F, Geuskens M and Kroemer G (1996) Mitochondrial permeability transition is a central coordinating event of apoptosis. J. Exp. Med. 184: 11551160

94. Simonian NA and Coyle JT (1996) Oxidative stress in neurodegenerative diseases. Annu. Rev. Pharmacol. Toxicol. 36: 83-106

95. Nicotera P, Leist M and Manzo L (1999) Neuronal cell death: a demise with different shapes. Trends Pharmacol. Sci. 20: 46-51

96. Chong MJ, Murray MR, Gosink EC, Russell HR, Srinivasan A, Kapsetaki M, Korsmeyer SJ and McKinnon PJ (2000) Atm and Bax cooperate in ionizing radiation-induced apoptosis in the central nervous system. Proc. Natl. Acad. Sci. U.S.A. $97: 889-894$

97. Liu ZG, Baskaran R, Lea-Chou ET, Wood LD, Chen Y, Karin M and Wang JY (1996) Three distinct signalling responses by murine fibroblasts to genotoxic stress. Nature 384: 273-276

98. Gibson S, Widmann C and Johnson GL (1999) Differential involvement of MEK kinase 1 (MEKK1) in the induction of apoptosis in response to microtubuletargeted drugs versus and damaging agents. J. Biol. Chem. 274: 1091610922

99. Fuchs SY, Adler V, Pincus MR and Ronai Z (1998) MEKK1/JNK signaling stabilizes and activates p53. Proc. Natl. Acad. Sci. U.S.A. 95: 10541-10546

100. Bulavin DV, Saito S, Hollander MC, Sagaguchi K, Anderson CW, Appella E and Fornace Jr AJ (1999) Phosphorylation of human p53 by p38 kinase coordinates $\mathrm{N}$-terminal phosphorylation and apoptosis in response to UV radiation. EMBO J. 18: $6845-6854$

101. She QB, Chen N and Dong Z (2000) ERKs and p38 kinase phosphorylate p53 protein at serine 15 in response to UV radiation. J. Biol. Chem. 275: 2044420449

102. Xia Z, Dickens M, Raingeaud J, Davis RJ and Greenberg ME (1995) Opposing effects of ERK and JNK-p38 MAP kinases on apoptosis. Science 270: 1326 1331

103. Dudek H, Datta SR, Franke TF, Birnbaum MJ, Yao R, Cooper GM, Segal RA, Kaplan DR and Greenberg ME (1997) Regulation of neuronal survival by the serine-threonine protein kinase Akt. Science 275: 661 -665

104. Philpott KL, McCarthy MJ, Klippel A and Rubin LL (1997) Activated phosphatidylinositol 3-kinase and Akt kinase promote survival of superio cervical neurons. J. Cell. Biol. 139: 809-815

105. Datta SR, Dudek H, Tao X, Masters S, Fun H, Gotoh Y and Greenberg ME (1997) Akt phosphorylation of BAD couples survival signals to the cell-intrinsic death machinery. Cell 91:231-241

106. Zha J, Harada H, Yang E, Jockel J and Korsmeyer SJ (1996) Serine phosphorylation of death agonist $B A D$ in response to survival factor results in binding to 14-3-3 not BCL-X(L). Cell 87: 619-628 
107. Mazzoni IE, Said FA, Aloyz R, Miller FD and Kaplan D (1999) Ras regulates sympathetic neuron survival by suppressing the p53-mediated cell death pathway. J. Neurosci. 19: 9716-9727

108. Deckwerth TL, Elliott JL, Knudson CM, Johnson Jr EM, Snider WD and Korsmeyer SJ (1996) BAX is required for neuronal death after trophic factor deprivation and during development. Neuron 17: 401-411

109. Ryan KM, Ernst MK, Rice NR and Vousden KH (2000) Role of NF-kappaB in p53-mediated programmed cell death. Nature 404: 892-897

110. Nonaka S and Chuang DM (1998) Neuroprotective effects of chronic lithium on focal cerebral ischemia in rats. NeuroReport 9: 2081-2084

111. XuX, Yang D, Wyss-Coray T, Jan J, Gan L, Sun Y and Mucke L (1999) Wild-type but not Alzheimer-mutant amyloid precursor protein confers resistance against p53-mediated apoptosis. Proc. Natl. Acad. Sci. U.S.A. 96: 7547-7552

112. Kern SE, Kinzler KW, Bruskin A, Jarosz D, Friedman P, Prives $C$ and Vogelstein B (1991) Identification of p53 as a sequence-specific DNA-binding protein. Science 252: $1708-1711$

113. Seto E, Usheva A, Zambetti GP, Momand J, Horikoshi N, Weinmann R, Levine AJ and Shenk T (1992) Wild-type p53 binds to the TATA-binding protein and represses transcription. Proc. Natl. Acad. Sci. U.S.A. 89: 12028-12032

114. Levine AJ (1997) p53, the cellular gatekeeper for growth and division. Cell 88 : $323-331$

115. May P and May E (1999) Twenty years of $p 53$ research: structural and functional aspects of the p53 protein. Oncogene 18: 7621-7636

116. Miyashita T, Krajewski S, Krajewska M, Wang HG, Lin HK, Liebermann DA, Hoffman B and Reed JC (1994) Tumor suppressor 553 is a regulator of bcl-2 and bax gene expression in vitro and in vivo. Oncogene 9: 1799-1805

117. Buckbinder L, Talbott R, Velasco-Miguel S, Takenaka I, Faha B, Seizinger BR and Kley N (1995) Induction of the growth inhibitor IGF-binding protein 3 by $p 53$. Nature 377: 646-649

118. Reinke $V$ and Lozano $G$ (1997) The 553 targets $m d m 2$ and Fas are not required as mediators of apoptosis in vivo. Oncogene 15: 1527-1534

119. Kobayashi T, Ruan S, Jabbur JR, Consoli U, Clodi K, Shiku H, Owen-Schaub LB, Andreef M, Reed JC and Zhang W (1998) Differential p53 phosphorylation and activation of apoptosis-promoting genes Bax and Fas/APO-1 by irradiation and ara-C treatment. Cell Death Differ. 5: 584-591

120. PolyakK, XiaY,ZweierJL, KinzlerKW and Vogelstein B(1997)A model for p53induced apoptosis. Nature 389: 300-305

121. Brodsky MH, Nordstrom W, Tsang G, Kwan E, Rubin GM and AbramsJM (2000) Drosophila p53 binds a damage response element at the reaper locus. Cell 101 $103-113$

122. Prisco M, Hongo A, Rizzo MG, Sacchi A and Baserga R (1997) The insulin-like growth factor I receptor as a physiologically relevant target of p53 in apoptosis caused by interleukin-3 withdrawal. Mol. Cell. Biol. 17: 1084-1092

123. Murphy M, Hinman A and Levine AJ (1996) Wild-type p53 negatively regulates the expression of a microtubule-associated protein. Genes Dev. 10: $2971-$ 2980

124. Li PF, Dietz R and von Harsdorf $R$ (1999) p53 regulates mitochondrial membrane potential through reactive oxygen species and induces cytochrome c-independent apoptosis blocked by Bcl-2. EMBO J. 18: 6027-6036

125. Deckwerth TL and Johnson Jr EM (1993) Temporal analysis of events associated with programmed cell death (apoptosis) of sympathetic neurons deprived of nerve growth factor. J. Cell. Biol. 123: 1207-1222

126. Vayssiere JL, Petit PX, Risler $Y$ and Mignotte B (1994) Commitment to apoptosis is associated with changes in mitochondrial biogenesis and activity in cell lines conditionally immortalized with simian virus 40. Proc. Natl. Acad. Sci. U.S.A. 91: $11752-11756$

127. Zamzami N, Marchetti $\mathrm{P}$, Castedo M, Zanin C, Vayssiere JL, Petit PX and Kroemer G (1995) Reduction in mitochondrial potential constitutes an early irreversible step of programmed lymphocyte death in vivo. J. Exp. Med. 181: $1661-1672$

128. Petit PX, Lecoueur H, Zorn E, Dauguet C, Mignotte B and Gougeon ML (1995) Alterations in mitochondrial structure and function are early events of dexamethasone-induced thymocyte apoptosis. J. Cell Biol. 130: 157-167

129. Cregan SP, MacLaurin JG, Craig CG, Robertson GS, Nicholson DW, Park DS and Slack RS (1999) Bax-dependent caspase-3 activation is a key determinant in p53-induced apoptosis in neurons. J. Neurosci. 19: 7860-7869

130. Hsu YT, Wolter WG and Youle RJ (1997) Cytosol-to-membrane redistribition of Bax and Bcl-X(L) during apoptosis. Proc. Natl. Acad. Sci. U.S.A. 94: 36683672
131. Wolter KG, Hsu YT, Smith CL, Nechushtan A, Xi XG and Youle RJ (1997) Movement of Bax from the cytosol to mitochondria during apoptosis. J. Cell Biol. 139: $1281-1292$

132. Nechushtan A, Smith CL, Hsu YT and Roule RJ (1999) Conformation of the Bax C-terminus regulates subcellular location and cell death. EMBO J. 18: 2330 2341

133. McGinnis KM, Gnegy ME and Wang KK (1999) Endogenous bax translocation in SH-SY5Y human neuroblastoma cells and cerebellar granule neurons undergoing apoptosis. J. Neurochem. 72: 1899-1906

134. Putcha GV, Deshmukh M and Johnson Jr EM (1999) BAX translocation is a critical event in neuronal apoptosis: regulation by neuroprotectants, BCL-2, and caspases. J. Neurosci. 19: 7476-7485

135. Xiang J, Chao DT and Korsmeyer SJ (1996) BAX-induced cell death may not require interleukin 1 beta-converting enzyme-like proteases. Proc. Natl. Acad. Sci. U.S.A. 93: 14559-14563

136. Vekrellis K, McCarthy MJ, Watson A, Whitfield J, Rubin LL and Ham J (1997) Bax promotes neuronal cell death and is downregulated during the development of the nervous system. Development 124: 1239-1249

137. Martinou I, Missotten M, Fernandez PA, Sadoul R and Martinou JC (1998) Bax and Bak proteins require caspase activity to trigger apoptosis in sympathetic neurons. NeuroReport 9: 15-19

138. Marzo I, Brenner C, Zamzami N, Jurgensmeier JM, Susin SA, Vieira HL, Prevost MC, Xie Z, Matsuyama S, Reed JC and Kroemer G (1998) Bax and adenine nucleotide translocator cooperate in the mitochondrial control of apoptosis. Science 281: 2027-2031

139. Schuler M, Bossy-Wetzel E, Goldstein JC, Fitzgerald P and Green DR (2000) p53 induces apoptosis by caspase activation through mitochondrial cytochrome c release. J. Biol. Chem. 275: 7337-7342

140. Johnson MD, Kinoshita Y, Xiang H, Ghatan S and Morrison RS (1999) Contribution of p53-dependent caspase activation to neuronal cell death declines with neuronal maturation. J. Neurosci. 19: 2996-3006

141. Ghatan S, Larner S, Kinoshita Y, Hetman M, Patel L, Xia Z, Youle RJ and Morrison RS (2000) p38 MAP kinase mediates Bax translocation in nitric oxideinduced apoptosis in neurons. J. Cell. Biol. 150: 335-348

142. Fuchs EJ, McKenna KA and Bedi A (1997) p53-dependent DNA damageinduced apoptosis requires Fas/APO-1-independent activation of CPP32beta. Cancer Res. 57: 2550-2554

143. Sabbatini P, Han J, Chiou SK, Nicholson DW and White E (1997) Interleukin 1 beta converting enzyme-like proteases are essential for p53-mediated transcriptionally dependent apoptosis. Cell Growth Differ. 8: 643-653

144. Soengas MS, Alarcon RM, Yoshida H, Giaccia AJ, Hakem R, Mak TW and Lowe SW (1999) Apaf-1 and caspase-9 in p53-dependent apoptosis and tumor inhibition. Science 284: 156-159

145. McCarthy NJ, Whyte MK, Gilbert CS and Evan GI (1997) Inhibition of Ced-3/ ICE-related proteases does not prevent cell death induced by oncogenes, DNA damage, or the Bcl-2 homologue Bak. J. Cell Biol. 136: 215-227

146. Miller TM, MoulderKL, Knudson CM, Creedon DJ, Deshmukh M, Korsmeyer SJ and Johnson Jr EM (1997) Bax deletion further orders the cell death pathway in cerebellar granule cells and suggests a caspase-independent pathway to cell death. J. Cell Biol. 139: 205-217

147. Lindenboim L, Yuan J and Stein R. (2000) Bcl-xS and Bax induce different apoptotic pathways in PC12 cells. Oncogene 19: 1783-1793

148. Ishitani R and Chuang DM (1996) Glyceraldehyde-3-phosphate dehydrogenase antisense oligodeoxynucleotides protect against cytosine arabinonucleoside-induced apoptosis in cultured cerebellar neurons. Proc. Natl. Acad. Sci. U.S.A. 93: $9937-9941$

149. Attardi LD, ReczekEE, Cosmas C, Demicco EG, McCurrach ME, Lowe SW and Jacks T (2000) PERP, an apoptosis-associated target of $\mathrm{p} 53$, is a novel member of the PMP-22/gas3 family. Genes Dev. 14: 704-718

150. Prives $C$ and Hall PA (1999) The p53 pathway. J. Pathol. 187: 112-126

151. Yu J, Zhang L, Hwang PM, Rago C, Kinzler KW and Vogelstein B (1999) Identification and classification of p53-regulated genes. Proc. Natl. Acad. Sci. U.S.A. 96: $14517-14522$

152. Levrero M, De Laurenzi V, Costanzo A, Gong J, Wang JY and Melino G (2000) The p53/p63/p73 family of transcription factors: overlapping and distinct functions. J. Cell Sci. 113: 1661-1670

153. Lohrum MA and Vousden $\mathrm{KH}$ (2000) Regulation and function of the p53-related proteins: same family, different rules. Trends Cell Biol. 10: 197-202 
154. Schreiber SS, Sakhi S, Dugich-Djordjevic MM and Nichols NR (1994) Tumor suppressor p53 induction and DNA damage in hippocampal granule cells after adrenalectomy. Exp. Neurol. 130: 368-376

155. Kitamura Y, Shimohama S, Kamoshima W, Matsuoka Y, Nomura Y and Taniguchi T (1997) Changes of p53 in the brains of patients with Alzheimer's disease. Biochem. Biophys. Res. Commun. 232: 418-421

156. Kohji T, Hayashi M, Shioda K, Minagawa M, Morimatsu Y, Tamagawa K and Oda M (1998) Cerebellar neurodegeneration in human hereditary DNA repair disorders. Neurosci. Lett. 243: 133-136

157. Li Y, Chopp M, Zhang ZG, Zaloga C, Niewenhuis L and Gautam S (1994) p53immunoreactive protein and p53 mRNA expression after transient middle cerebral artery occlusion in rats. Stroke 25: 849-855

158. Tomasevic G, Kamme F, Stubberod P, Wieloch M and Wieloch T (1999) The tumor suppressor $\mathrm{p} 53$ and its response gene p21WAF/Cip1 are not markers of neuronal death following transient global cerebral ischemia. Neuroscience 90 : $781-792$

159. Joo CK, Choi JS, Ko HW, Park KY, Sohn S, Chun MH, Oh YJ and Gwag BJ (1999) Necrosis and apoptosis after retinal ischemia: involvement of NMDAmediated excitotoxicity and p53. Invest. Ophthalmol. Vis. Sci. 40: 713-720

160. Manev H, Kharlamov A and Armstrong DM (1994) Photochemical brain injury in rats triggers DND fragmentation, p53 and HSP72. NeuroReport 5: 2661-2664

161. Hughes PE, Alexi T, Yoshida T, Schreiber SS and Knusel B (1996) Excitotoxic lesion of rat brain with quinolinic acid induces expression of p53 messenger RNA and protein and p53-inducible genes Bax and Gadd-45 in brain areas showing DNA fragmentation. Neuroscience 74: 1143-1160
162. Kaya SS, Mahmood A, Li Y, Yavuz E, Goksel M and Chopp M (1999) Apoptosis and expression of p53 response proteins and cyclin D1 after cortical impact in rat brain. Brain Res. 818: 23-33.

163. Daily D, Barzilai A, Offen D, Kamsler A, Melamed E and Ziv I (1999) The involvement of p53 in dopamine-induced apoptosis of cerebellar granule neurons and leukemic cells overexpressing p53. Cell. Mol. Neurobiol. 19:261 276

164. Blum D, Wu Y, Nissou MF, Arnaud S, Alim Louis B and Verna JM (1997)p53 and Bax activation in 6-hydroxydopamine-induced apoptosis in PC12 cells. Brain Res. 751: 139-142

165. Eizenberg O, Faber-Elman A, Gottlieb E, Oren M, Rotter V and Schwartz M (1996) p53 plays a regulatory role in differentiation and apoptosis of central nervous system-associated cells. Mol. Cell. Biol. 16: 5178-5185

166. Sadoul R, Quiquerez AL, Martinou I, Fernandez PA and Martinou JC (1996) p53 protein in sympathetic neurons: cytoplasmic localization and no apparent function in apoptosis. J. Neurosci. Res. 43: 594-601

167. Davies AM and Rosenthal A (1994) Neurons from mouse embryos with a nul mutation in the tumour suppressor gene p53 undergo normal cell death in the absence of neurotrophins. Neurosci. Lett. 182: 112-114 